where he annoyed fellow scientists with his grandiosity. His self-delusion persisted: early in 1945, after a special allied mission had raced across a collapsing Germany to apprehend him, Heisenberg arrogantly assumed that he held a powerful bargaining position and evidently failed to grasp that he was a prisoner. When he heard that the United States had dropped an atomic bomb on Hiroshima, at first he refused to believe it, claiming that some "dilettante" American had to be bluffing.

Although such scenes make Serving the Reich a page-turner, Ball keeps the moral and existential ambiguities at the forefront. He lets us see that for many scientists, to abandon one's work and post - especially during such a crisis would seem "a dereliction of duty, not a moral act of protest". And defying the Nazis was not always an act of rebellion: Planck's insistence on holding a memorial in 1935 on the first anniversary of the Jewish scientist Fritz Haber's death was less a protest against anti-Semitism than an honour extended to a deceased, esteemed colleague.

But Ball has no sympathy for journalists who have bought scientists' self-serving apologies or condemned the scientists on the basis of cherry-picked evidence. Dutch journalist Sybe Rispens's 2006 accusation that Debye was a Nazi sympathizer, for instance, led the University of Utrecht in the Netherlands to drop the physicist's name from its nanomaterials institute.

Ball insists that, rather than simplistically condemning or absolving the German scientists, we should look at their moral behaviour as a perpetually open question. Most daringly, he suggests that the way they coped with entanglements of science, politics and life is still representative of scientists now. By the end of this book, careful readers will be left with the queasy feeling that our own moral high ground has disappeared, and that Ball has revealed the 'soul' of physics to be no more intrinsically noble than any other.

Robert P. Crease is professor of philosophy at Stony Brook University, New York, and author of World in the Balance. e-mail:robert.crease@stonybrook.edu

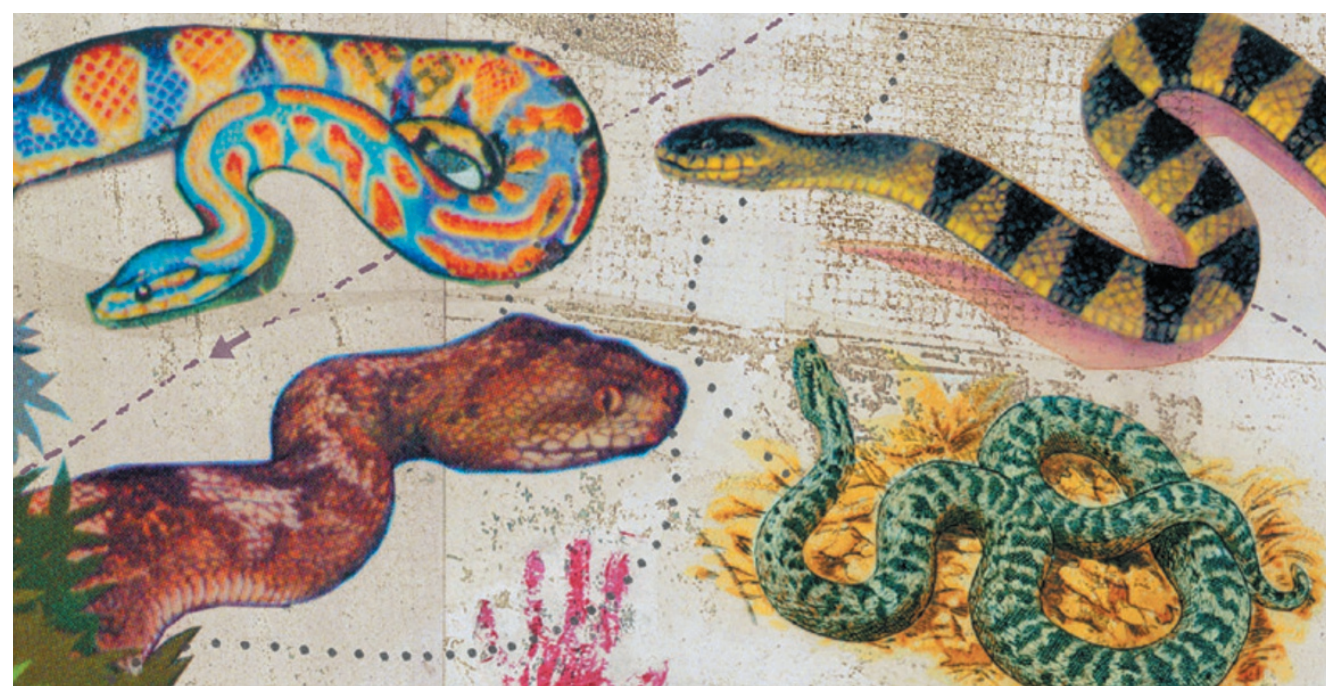

BIOLOGY

\title{
The love of pit vipers
}

\section{Stuart Pimm follows a fellow biologist's evolution from wide-eyed wonder to a life chasing snakes in the field.}

I shake the hand of my fellow guide on a tour group along the Amazon. Feeling missing fingers, I blurt out, "You're a herpetologist?" Quickly forgiving me, he names the species of snake responsible. Harry Greene, in his engaging autobiography Tracks and Shadows, tells us of others who have lost digits. Greene himself still has a full set. He has been lucky - and careful.

We learn much about snakes from Greene, but more about the academic lineages and personalities that shaped his field. Greene and I are academic cousins, sharing a distant academic ancestor in the form of field biologist Joseph Grinnell, who worked at the University of California, Berkeley, from 1908 until his death in 1939. The theme of Greene's book is that the shadows cast by academic family mould our lives, but so do the species we track.

The field guide is the beginning. I vividly remember getting my first. It had to be of birds (my lifelong passion), because all Britain's amphibians and reptiles would form a

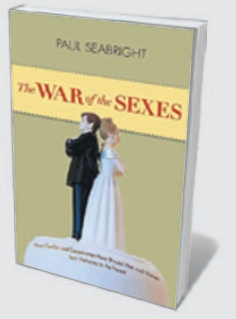

The War of the Sexes: How Conflict and Cooperation Have Shaped Men and Women from Prehistory to the Present

Paul Seabright (Princeton University Press, 2013)

An economist examines animals' tactics for ensuring reproduction, and ponders how human evolution can explain gender inequities in the West. (See John Whitfield's review: Nature 484, 317; 2012.)

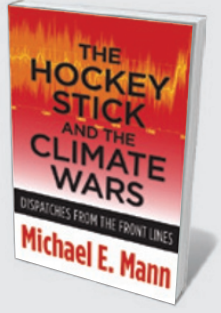

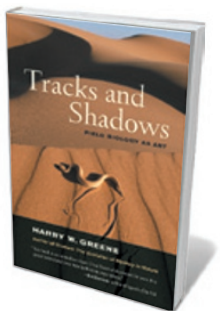

Tracks and Shadows: Field Biology as Art HARRY W. GREENE University of California Press: 2013. him thinking, "I want to see that one. No, that's the one I just have to find!" And although the taxa differed, the experiences and outcomes were the same: we had to find what we saw that so intrigued us.

Two things follow. Soon, you are looking in places where you might find the real thing. Creeks, wetlands, woodlots and barren land - all places others might pass Only in graduate school in the Ameritaxonomic passion was set, did I meet the groundbreaking guides to America's exceptional diversity of amphibians and reptiles by Robert Stebbins and Roger Conant. Greene flips through Conant's pages, and I imagine small volume indeed. can West, when my e (n) (n)

(n)

(n)

\section{The Hockey Stick and the Climate Wars:} Dispatches from the Front Lines Michael E. Mann (Columbia University Press, 2013) Meteorologist Michael Mann recounts the attack on his seminal 1998 global warming paper. The lengths to which deniers have gone to discredit the research continue to astound. (See Simon Lewis' review: Nature 483, 402-403; 2012.) 


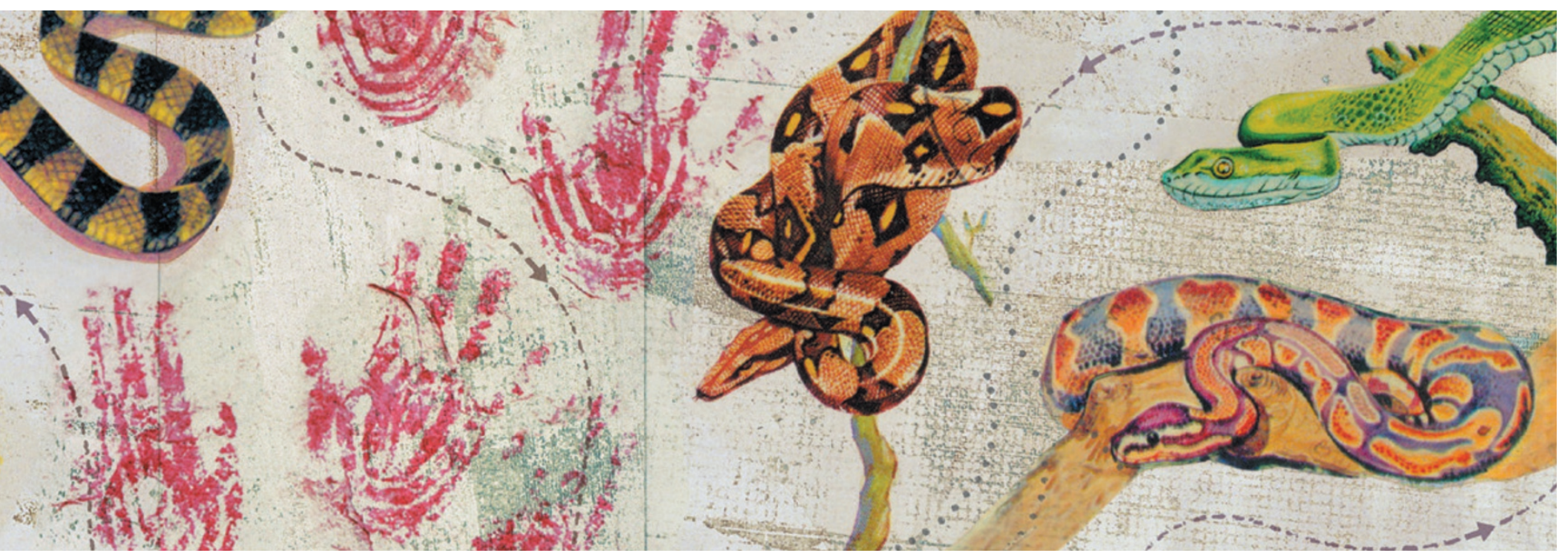

without notice - become magical when one thinks they might hold desired species. Here, my path diverges from Greene's. I have never wished to turn over old planks to find rattlesnakes, to have my heart race as I pick up a cottonmouth, or to have to conceal being bitten by a copperhead from my parents.

The second discovery is that there are people just like you, with the same eccentricities, whose mentoring is vital. Greene writes a deeply respectful chapter about the herpetologist Henry Fitch, whom he met shortly after finishing high school. The sheer joy of learning more about natural history becomes an obsession, and mentors such as Fitch prove that it can be life-long. It carried Greene through an early job as a mortician's assistant, then the unavoidable Vietnam War years. As a medic, he looked after people battered and disabled by the conflict and contemplated his own imminent departure for battle. Sightings of whip-tailed lizards and black-tailed rattlesnakes near the training hospital provided welcome distractions. Seven of his colleagues were then posted to Vietnam and their fates still haunt him; he was posted to Germany.

After military service, graduate school was the University of Tennessee with a superb set of professors who, soon after Greene left, became my colleagues for 17 years. Greene's adviser, Gordon Burghardt, challenged him to think like a snake. "What are the private experiences of animals?” Burghardt asks.

For the next two decades, Greene was at Berkeley, where he inherited Grinnell's desk. In those decades, technology made thinking like a snake easier. Radio transmitters revolutionized snake biology by allowing access to their secret lives.

Greene radio tracked rattlesnakes in deserts and bushmasters in rainforests, understanding what exceptional predators they are. We tend to view lions and tigers as

\section{TRACKS AND SHADOWS IS AS PACKED WITH PEOPLE AND DRAMA AS A NOVEL.}

iconic hunters. Snakes, especially poisonous ones, are very different. They may sit and wait, catching prey only three to five times each year, yet must be ready to strike in a fraction of a second. Then, remarkably, they must use their tongue to sense the scent trail along which the fatally poisoned victim is fleeing. Digestion can take a week or more.

Sex is different too. Jesús Rivas, another of Burghardt's students, found his green anacondas by feeling for them with his bare feet in the muck of the Venezuelan Llanos, a tropical grassland. Think like an anaconda: males are much smaller than the females. "Imagine lying for hours in ... a tropical slough, among a dozen seven-foot suitors for an eighteen-foot female, entangling your muscular, scaly tail with others competing for her vent." Males may need to be large enough to compete, but not so large as to be mistaken for a female, he explains.

Tracks and Shadows is as packed with people and drama as a novel, as Greene ventures forth with friends and revered mentors, records marriages and divorces, happiness and tragedies - some via snakebites - all uniquely wrapped in his herpetologist's world. As the 'art' in the subtitle indicates, he sees similarities between the immersive work of field biology and the worlds of the Amerindian rock artists of Texas and the painters of the caves at Chauvet in France - ancients who suffered life's vagaries in direct connection to the living world. Animals dominate as images. Modernity separates most of us from that life, but not so field biologists.

Stuart Pimm is professor of conservation at the Nicholas School of the Environment, Duke University, Durham, North Carolina, USA, and author of The World According to Pimm: a Scientist Audits the Earth. e-mail:stuartpimm@me.com

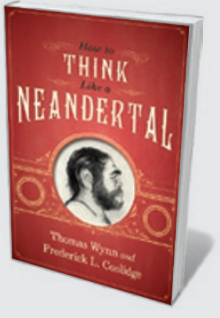

How to Think Like a Neandertal

Thomas Wynn and Frederick L. Coolidge (Oxford University Press, 2013)

This study of mental similarities between Homo sapiens and Neanderthals suggests that the powerful early humans had language, attended to their dead - and might have appreciated slapstick. (See Clive Gamble's review: Nature 479, 294-295; 2011.)

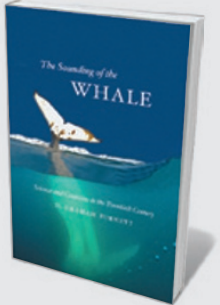

The Sounding of the Whale: Science and Cetaceans in the Twentieth Century D. Graham Burnett (University of Chicago Press, 2013)

Sobering insights abound in a history of cetacean science that powerfully reflects the mixed human response to Earth's largest mammal. (See Philip Hoare's review: Nature 481, 141-142; 2012.) 